\title{
Physiological responses and P5CS gene expression of transgenic oil palm plantlet induced by drought stress
}

\author{
Respons fisiologis dan ekspresi gen P5CS pada planlet kelapa sawit transgenik terhadap induksi cekaman \\ kekeringan
}

\author{
TURHADI*), Hayati MINARSIH, Imron RIYADI, PRIYONO, \& Asmini BUDIANI
}

Indonesian Research Institute for Biotechnology and Bioindustry, Jl. Taman Kencana No.1, Bogor 16128, Indonesia

Diterima tgl 9 Juni 2020 / disetujui tgl 25 Agustus 2020

\begin{abstract}
Abstrak
Kekeringan merupakan salah satu faktor pembatas dalam budidaya tanaman, seperti halnya pada kelapa sawit (Elaeis guineensis Jacq.). Pendekatan transgenik diharapkan mampu meningkatkan toleransi tanaman terhadap cekaman kekeringan dan meminimalisir rendahnya produktivitas saat terjadinya kekeringan. Prolin sebagai salah satu senyawa osmoprotektan pada tanaman yang biosintesisnya melibatkan gen P5CS dijadikan target rekayasa dalam penelitian ini. Penelitian ini bertujuan mengevaluasi tingkat ketahanan planlet kelapa sawit transgenik P5CS terhadap cekaman kekeringan menggunakan senyawa polietilena glikol 6000 (PEG-6000). Pada penelitian ini planlet kelapa sawit transgenik yang disisipi gen P5CS dan non-transgenik diperlakukan dengan PEG-6000 0, 2, dan 4\% secara in vitro. Rancangan acak lengkap faktorial dengan tiga ulangan digunakan dalam penelitian ini. Skor tingkat kekeringan, kandungan klorofil total, kandungan karotenoid, kandungan prolin, dan ekspresi gen P5CS pada jaringan daun diamati pada 7 dan 14 hari setelah perlakuan cekaman. Hasil penelitian menunjukkan bahwa tanaman transgenik mempunyai skor tingkat kekeringan yang lebih rendah dibandingkan non-transgenik. Cekaman PEG-6000 pada konsentrasi 4\% menurunkan kandungan klorofil total dan karotenoid yang lebih besar dibandingkan dengan konsentrasi $2 \%$ pada tanaman non-transgenik pada 7 dan 14 hari setelah perlakuan (HSP). Selain itu, tanaman transgenik mengalami peningkatan akumulasi prolin dan ekspresi gen P5CS selama perlakuan cekaman. Hasil ini menunjukkan bahwa transgen P5CS mampu meningkatkan toleransi tanaman kelapa sawit terhadap cekaman kekeringan.
\end{abstract}

[Kata kunci: karotenoid, klorofil, kekeringan, toleransi kekeringan, prolin]

\begin{abstract}
Drought is one of the limiting factors in crop cultivation, such as in oil palm (Elaeis guineensis Jacq.). The transgenic approaches are expected to increase plant tolerance to drought stress and minimize low productivity when drought occurs. Proline is an osmoprotectant compound in plants which its biosynthesis involved the P5CS gene. The objective of this study was to evaluate the tolerance level of $P 5 C S$-transgenic oil palm to drought stress induced by polyethylene glycol 6000 (PEG-6000). In this present study, the transgenic and non-transgenic oil palms were treated by 0,2 , and 4\% PEG-6000 under in vitro conditions. The experiment was arranged as a factorial completely randomized design with three replications. The drought level score, total chlorophyll content, carotenoids, and proline content, as well as P5CS gene expression in leaf tissues were observed at 7 and 14 days after stress treatments. The result showed that transgenic plantlets had a lower drought level score than those of non-transgenic lines. A concentration of $4 \%$ PEG-6000 treatment reduced the total chlorophyll and carotenoids contents than that of $2 \%$ concentration in non-transgenic plantlets at 7 and 14 day after treatments (DAT). In addition, proline content and P5CS gene expression level in transgenic had been significantly increased during stress treatment. Based on these results, it can be concluded that the P5CS transgene increased the drought stress tolerance of oil palm.
\end{abstract}

[Keywords: carotenoids, chlorophyll, drought, drought tolerance, proline]

\section{Introduction}

Oil palm (Elaeis guineensis Jacq.) is one of the important economic oil crops in the world. Oil palm has the highest yield per hectare of all oil crops, such as soy bean, rapeseed, and sunflower.

${ }^{*}$ Corresponding author: turhadibiologi@gmail.com 
Moreover, palm oil is the largest source of vegetable oil (Corley \& Tinker, 2016). Indonesian Statistics (BPS, 2019) reported that during the year 2000-2018, the production of Indonesian oil palm increased $80.87 \%$, while export activity of crude palm oil (CPO) increased $85.27 \%$.

Since the drought stress has become a main problem in various crop cultivation, the breeding strategy to develop drought tolerance varieties has long been attempted, include in oil palm. Drought has negative effect on crop growth and development, and its effect varies among the severity of stress, growth stage, and genetic background (Din et al., 2011; Farooq et al., 2012; Lum et al., 2014; Yehouessi et al., 2019). Previous studies also reported that drought stress reduce the photosynthesis activity and increase the free proline level in tall fescue (Festuca arundinacea) (Man et al., 2011), sugarcane (Abbas et al., 2014), rice (Todaka et al., 2017), teak (Tectona grandis L.f.) (Galeano et al., 2019), and maize (Voronin et al., 2019). Effects of drought stress on morphophysiological, biochemical, molecular level have been reported in oil palm (Cha-um et al., 2010; Jazayeri et al., 2015; Rivera-Mendes et al., 2016; Kaur \& Asthir, 2017; Yehouessi et al., 2019; Fauzi \& Putra, 2019; Amanah et al., 2019). Darlan et al. (2016) found that oil palm production due to drought caused by $\mathrm{El}$ Nino phenomenon in Indonesia could reach $30-60 \%$ reduction.

Drought stress tolerance in plants is one of the complex traits and controlled by many genes (Ashraf, 2010). Maintaining excess water loss during stress through osmoprotectants or compatible solutes known as a tolerance strategy to drought. Proline accumulation is an adaptive response and also known as an osmoregulatory solute in plants under hyperosmotic stresses, such as drought (Iskandar et al., 2014). The $\Delta^{1}$ pyrroline-5-carboxylate synthetase (P5CS) is a rate limiting enzyme that has a role in proline biosynthesis which is encoded by P5CS gene (Kishor et al., 2005). Proline also reported as a biochemical marker under drought stress in plants (Toruan-Mathius et al., 2004; Ashraf, 2010; Fichman et al., 2015; Zarattini \& Forlani, 2017). In addition, drought stress has also been reported to interfere the photosynthetic system of plants as indicated by decreasing of chlorophyll content
(Din et al., 2011; Jazayeri et al., 2015). Besides reducing chlorophyll, drought stress also reduces carotenoids due to the increase of reactive oxygen species production (Mibei et al., 2017). As common non-enzymatic antioxidant, carotenoids protect cells from excess damage during the stress (Ghobadi et al., 2013). Chorophyll and carotenoids also reported as useful traits for identification the drought tolerance level of plants (Talebi et al., 2013).

The availability of drought tolerant of oil palm plant material is needed. One of strategy that can be conducted to obtain drought tolerant of oil palm is via genetic engineering. Transformation and genetic engineering in plants using the P5CS gene has been carried out on various plants, i.e. tobacco (Riduan et al., 2010; Zarei et al., 2012), sugarcane (Minarsih et al., 2015), wheat (Pavei et al., 2016), and oil palm (Budiani et al., 2019). Furthermore, Budiani et al. (2019) successfully developed P5CS-transformed oil palm embryonic calli into plantlets but these plantlets have not been evaluated yet under certain stress conditions, especially to drought stress. In the present study, we evaluated the physiological responses and P5CS gene expression of transgenic oil palm plantlets under drought stress using PEG-6000. The findings could be useful and become a basis knowledge for improving oil palm productivity under related water deficit stress.

\section{Materials and Methods}

\section{Plant materials}

The P5CS-transgenic oil palm (Tenera) plantlets on Murashige-Skoog culture medium under room with controlled temperature of $25^{\circ} \mathrm{C}$, with 20-25 cm height and 4-6 leaves were used in this study. The pBI-P5CS construct containing P5CS gene-encoded $\Delta^{1}$-pyrroline-5-carboxylate synthetase enzyme from Vigna aconitifolia (Figure 1) was kindly provided by Dr. Desh Pal S. Verma (Department of Molecular Genetics and Plant Biotechnology Center, The Ohio State University, USA) (Minarsih et al., 2001) and were then inserted to oil palm (Elaeis guineensis Jacq.) by Budiani et al. (2019).

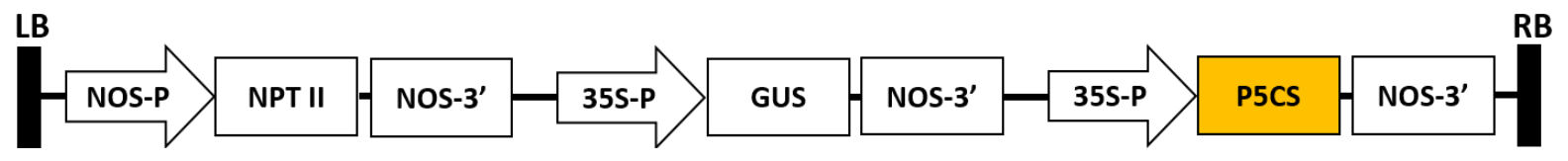

Figure 1. Construct map of pBI plasmid containing P5CS gene (pBI-P5CS)

Gambar 1. Peta konstruksi plasmid pBI dengan gen P5CS (pBI-P5CS) 


\section{Experiment conditions}

The experiment was conducted using Murashige-Skoog culture medium containing PEG-6000 as a drought treatment. There were three treatments in this study, i.e. 0\% PEG-6000 ($0.24 \mathrm{MPa}$ ) as control, 2\% PEG-6000 (-0.98 MPa), and 4\% PEG-6000 (-2.52 $\mathrm{MPa})$ as stress conditions according to Cha-um et al. (2010). These treatments were exposed to non-transgenic and P5CS transgenic plantlets with the criteria as described above. The experiment was arranged as a factorial completely randomized design with three replications $(n=3)$. Drought level score, total chlorophyll-, carotenoid-, proline content, and P5CS gene expression were measured in this study. These parameters were observed at 7 and 14 DAT.

Drought level score determination of oil palm under PEG-6000-induced stresses

The level of PEG-6000-induced drought was represented as a score of 0 (without drying area on the leaves) to 9 (the plant died) according to the leaf drying area at the vegetative stage (IRRI, 2002). The drought level score determination was done at 1,7 , and 14 DAT.

Total chlorophyll and carotenoid content determination

The total chlorophyll and carotenoid contents were extracted by acetone $80 \%$. Briefly, $100 \mathrm{mg}$ of fresh leaf from treated plants were ground in $10 \mathrm{~mL}$ of cold acetone $80 \%(\mathrm{v} / \mathrm{v})$ for total chlorophyll and carotenoid pigments extraction. The extract was centrifuged at $3000 \mathrm{~g}$ at $4{ }^{\circ} \mathrm{C}$ for 15 minutes (Turhadi et al., 2019). The supernatant was read at 470, 663, and $646 \mathrm{~nm}$ using Thermo Scientific $^{\text {TM }}$ Multiskan $^{\text {TM }}$ GO Microplate Spectrophotometer (Thermo Fisher Scientific Inc., USA). The chlorophyll and carotenoid were determined according to a formula by Lichtenthaler (1987) at 7 and 14 DAT in three plantlets in each treatments.

\section{Proline content determination}

Proline content was determined according to Bates et al. (1973). Briefly, $0.25 \mathrm{~g}$ of fresh leaf were ground using $5 \mathrm{~mL}$ of sulfosalicylic acid $3 \%$ $(\mathrm{w} / \mathrm{v})$. The extracts were centrifuged at $10000 \mathrm{rpm}$ at $25^{\circ} \mathrm{C}$ for 10 minutes. About $2 \mathrm{~mL}$ of supernatant was mixed with $2 \mathrm{~mL}$ of acid-ninhydrin reagent (1.25 g ninhydrin in $30 \mathrm{~mL}$ of glacial acetic acid and $20 \mathrm{~mL}$ of $6 \mathrm{M}$ phosporic acid) and $2 \mathrm{~mL}$ of glacial acetic acid. The mixture was then incubated at $100{ }^{\circ} \mathrm{C}$ for 1 hour and immediately soaked in ice water. The filtrate was extracted using $4 \mathrm{~mL}$ toluene and vortexed. The proline content of leaves which harvested on 7 and 14 DAT was determined at $\lambda \quad 520 \mathrm{~nm}$ using Thermo Scientific ${ }^{\mathrm{TM}}$ Multiskan $^{\mathrm{TM}}$ GO Microplate Spectrophotometer (Thermo Fisher Scientific Inc., USA).

$R N A$ isolation and quantitative real timepolymerase chain reaction ( $q R T-P C R$ )

P5CS gene expression level was done at 7 and 14 DAT. Total RNA was isolated from leaf tissues of treated plants using $\mathrm{TRIzol}^{\mathrm{TM}}$ reagent (Invitrogen, USA) according to the manufacturer's protocols. RNAs were treated with the DNase I kit (Sigma-Aldrich ${ }^{\circledR}$, USA) to remove contaminating genomic DNA according to the manufacturer's protocols. The cDNAs were then synthesized using AccuPower $^{\circledR}$ CycleScript RT Premix (dT20) (BIONEER, USA) according to the manufacturer's protocols. The synthesized cDNAs were used for the P5CS gene expression level by qRT-PCR. The P5CS primers used in the expression analysis was designed based on P5CS gene sequence of Vigna aconitifolia with Genbank accession no. M92276.1. The qRT-PCR in each sample was performed in triplicates using genespecific primers (Table 1) and SensiFAST ${ }^{\mathrm{TM}}$ SYBR $^{\circledR}$ Hi-ROX (Bioline, USA) according to the manufacturer's protocols. The Actin primer used for this quantification as a reference gene (Table $1)$. The expression level of the P5CS gene was quantified by $2^{-\Delta \Delta C t}$ formula (Schmittgen \& Livak, 2008).

\section{Statistical analysis}

Data were statistically analyzed using analysis of variance (ANOVA) $(\alpha=0.05)$ and correlation analysis $(\alpha=0.05)$. Analysis of variance was performed in SPSS 16.0 program (SPSS Inc., Chicago, IL, USA), while correlation analysis was performed and visualized in R-Studio program using corrplot package.

Table 1. Primers used in this study

Tabel 1. Primer yang digunakan pada penelitian ini

\begin{tabular}{lc}
\hline $\begin{array}{c}\text { Primer identity } \\
\text { Identitas primer }\end{array}$ & $\begin{array}{c}\text { Sequences } \\
\text { Sekuen }\end{array}$ \\
\hline Actin-F & CCCACCTGAACGGAAATACA \\
Actin-R & CGGATGGCACCTCAGTCTTA \\
qRT-P5CS-F & CGGTTGGAAGATTGGGAGCT \\
qRT-P5CS-R & TTGGGGTTTCTGAAGGTCGG \\
\hline
\end{tabular}




\section{Results and Discussion}

Drought level score of non- and transgenic oil palm under polyethylene glycol 6000-induced stresses

Non- and transgenic plantlets demonstrated different responses to drought stress treatment using PEG-6000 in this present study. Leaves of non-transgenic plantlets showed drought response in 4\% PEG-6000 at 7 DAT. The increase of PEG6000 concentration and longer duration of treatment caused an increase of drought symptom especially in non-transgenic oil palm plantlets as shown in Figure 2.

The drought level between transgenic and nontransgenic plantlet leaves showed clearly different at 14 DAT under 4\% PEG-6000 treatment. The leaves of the transgenic plantlets showed mostly green (average score $=1.0$ ), while non-transgenic plantlets showed brown color or dry (average score $=5.0$ ) (Figure 3). Lower scores indicated low level of drought stress and vice versa. These results indicated that $P 5 C S$-transgenic oil palm had higher tolerance level to drought stress than nontransgenic.
Total chlorophyll, carotenoids, and proline content in transgenic oil palm

The response of P5CS-transgenic oil palm to drought stress conditions was demonstrated by measuring several physiological parameters, i.e. total chlorophyll-, carotenoids-, and proline content in leaf tissues (Figure $4 a-d \& 5$ ). Total chlorophyll content significantly $(\mathrm{p}<0.05)$ decreased within interaction between genotypes and PEG-6000 concentration (Figure 4a). Transgenic plantlets showed higher total chlorophyll content than that of non-transgenic under 2 and 4\% PEG-6000 (Figure 4a). Total chlorophyll content of non-transgenic plantlets decreased by $61 \%$ in compared to the control at 14 DAT (Figure 4b). Conversely, the transgenic plantlets were able to maintain the total chlorophyll content even under PEG-6000 stresses. The total chlorophyll content in transgenic plantlets under 4\% PEG-6000 showed an increase of $31 \%$ and $15 \%$ at 7 and 14 DAT, respectively. Based on these responses indicated that P5CS transgene from Vigna aconitifolia increased the oil palm tolerance level to drought stress.

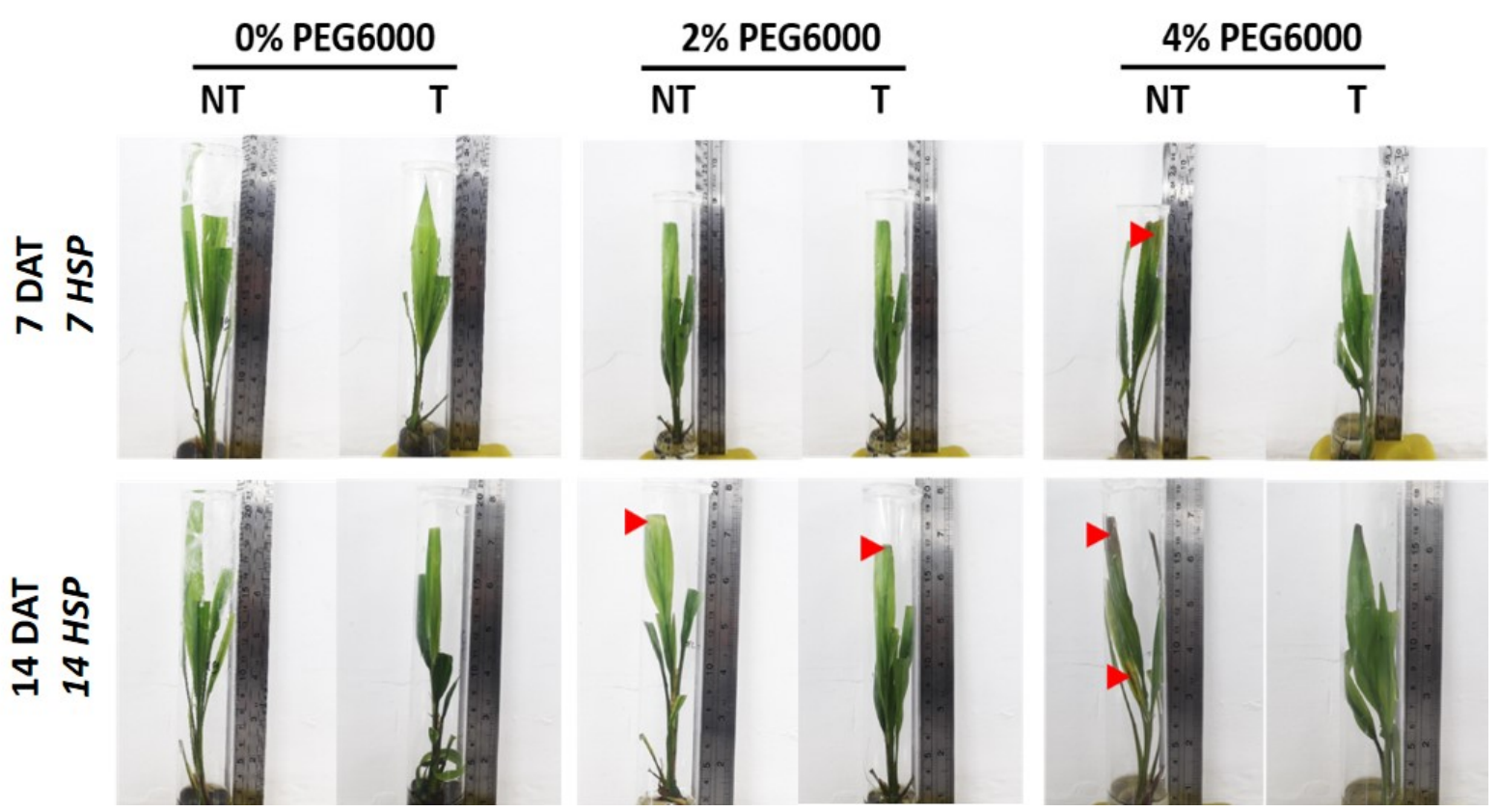

Figure 2. Leaf profiles of oil palm plantlets in 0, 2, and 4\% PEG-6000 during 14 days of in-vitro treatment. NT $=$ nontransgenic; $\mathrm{T}=$ transgenic. DAT $=$ day after treatment; 7 and $14=$ duration of treatment. Red arrows showed a drought leaf symptom

Gambar 2. Profil daun planlet kelapa sawit pada PEG-6000 0, 2, dan 4\% selama 14 hari perlakuan secara in-vitro. NT = non-transgenik; $T=$ transgenik. HSP = hari setelah perlakuan; 7 dan $14=$ lama perlakuan. Tanda panah warna merah menandakan gejala daun yang mengering 


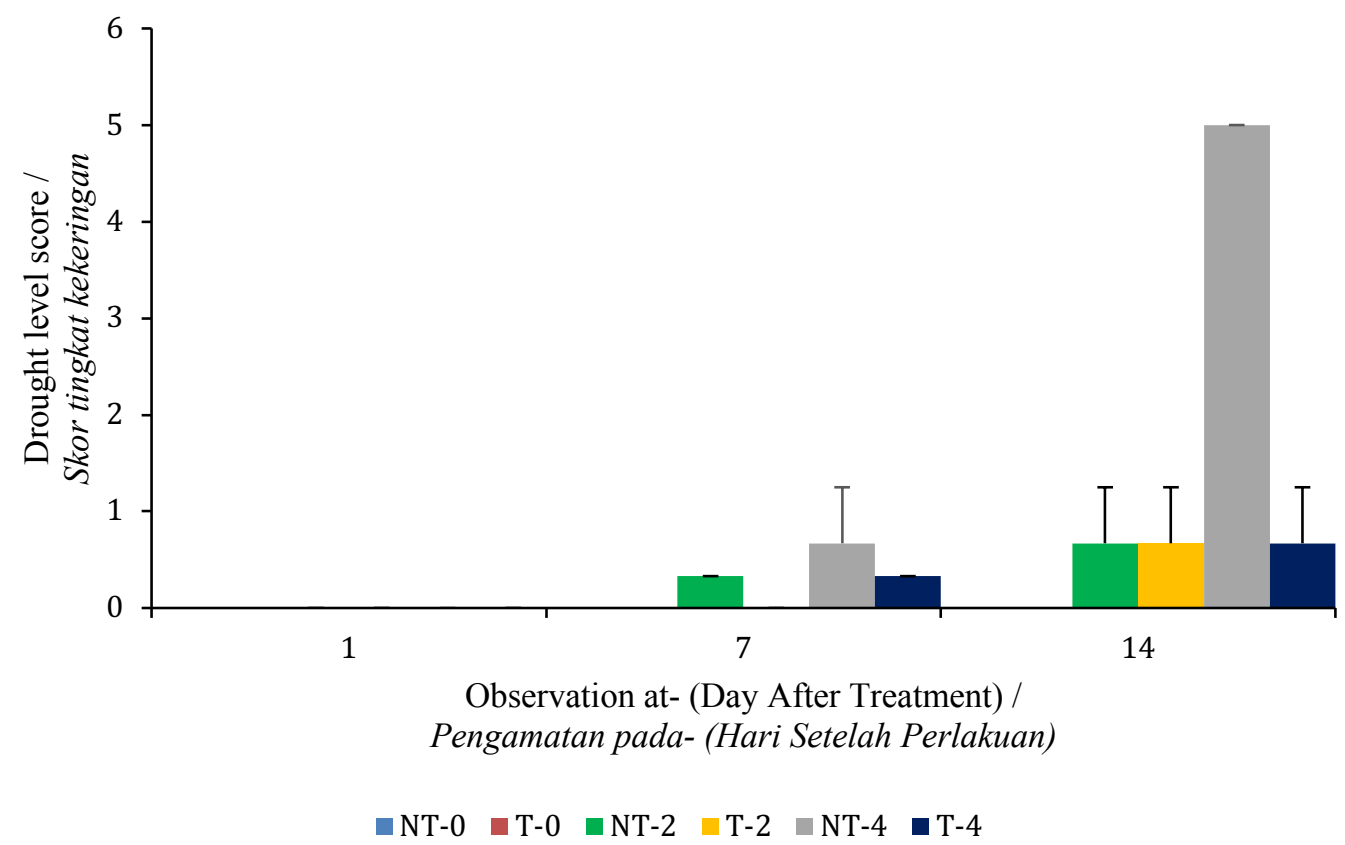

Figure 3. Drought level score of oil palm plantlets in 0, 2, and 4\% PEG-6000 during 14 days of in-vitro treatment. NT = non-transgenic; $\mathrm{T}=$ transgenic. 1,7 , and $14=$ duration of treatment

Gambar 3. Skor tingkat kekeringan planlet kelapa sawit pada PEG-6000 0, 2, dan 4\% selama 14 hari perlakuan secara in-vitro. $N T=$ non-transgenik; $T=$ transgenik. 1,7 , dan 14 = lama perlakuan
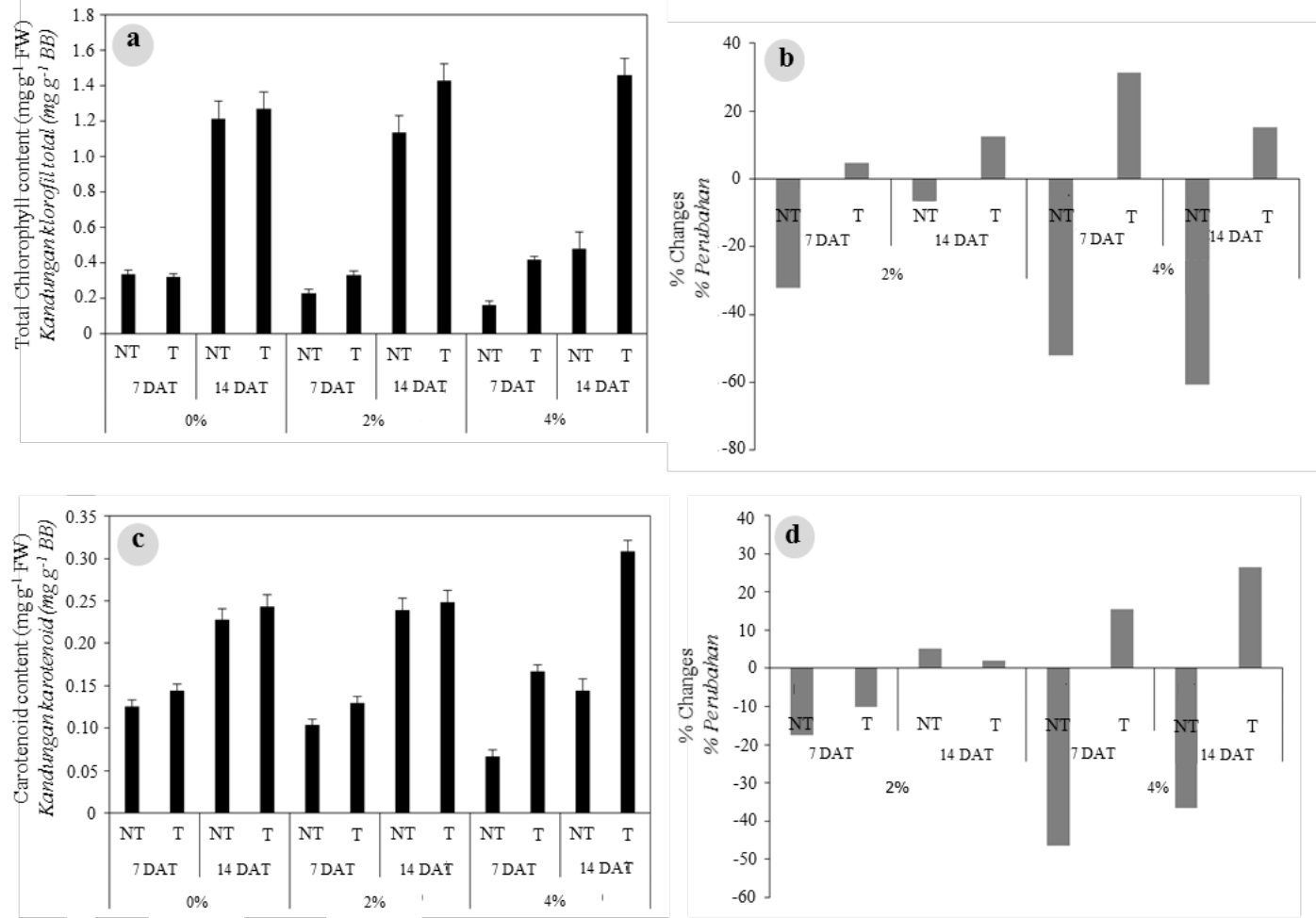

Figure 4. Total chlorophyll (a-b) and carotenoids (c-d) contents of oil palm plantlets in 0, 2, and 4\% PEG-6000 during 14 days of in-vitro treatment. NT $=$ non-transgenic; $\mathrm{T}=$ transgenic. DAT $=$ day after treatment; 7 and $14=$ duration of treatment. \% changes means percentage of increase/decrease in each parameter that calculated using formula $=(\mathrm{PEG}$ treatment - control $) /$ control $\times 100 \%$

Gambar 4. Kandungan klorofil total (a-b) dan karotenoid (c-d) planlet kelapa sawit pada PEG-6000 0, 2, dan 4\% selama 14 hari perlakuan secara in-vitro. $N T=$ non-transgenik; $T=$ transgenik. HSP = hari setelah perlakuan; 7 dan 14 = lama perlakuan. \% perubahan berarti persentase peningkatan/penurunan pada setiap peubah yang dihitung menggunakan rumus $=($ perlakuan PEG - kontrol $) /$ kontrol $\times 100 \%$ 
The decreasing of oil palm's chlorophyll content under PEG-6000 treatment using in-vitro conditions also reported in previous research studies (Cha-um et al., 2010, 2012). Moreover, the decreasing of chlorophyll content under drought stress also reported in oil palm using watering intensity treatments (Cha-um et al., 2013; Azzeme et al., 2016). In this present study, the decreasing of total chlorophyll content under PEG-6000 treatment was suggested due to the damage of chloroplast organelle during stress.

Beside of total chlorophyll content, the increase of tolerance level of transgenic oil palm plantlets was also shown in carotenoids profile content. There was significantly $(p<0.05)$ interaction between genotypes and PEG-6000 concentration to carotenoids content of oil palm plantlets. The carotenoids content of transgenic plantlets under 4\% PEG-6000 higher than that control and 2\% PEG-6000 (Figure 4c). Our result showed that carotenoids content of transgenic plantlets under $4 \%$ PEG-6000 increased by $16 \%$ and $26 \%$ at 7 and 14 DAT, respectively. Conversely, the carotenoids content of nontransgenic plantlets under $4 \%$ PEG-6000 decreased by $47 \%$ and $37 \%$ at 7 and 14 DAT, respectively (Figure $4 \mathrm{~d}$ ).

The increase of carotenoids content in transgenic plantlets suggested of having a role in the tolerance mechanism of oil palm to drought stress. Besides as light-harvesting pigment, carotenoids also have a role as chlorophyll protecting pigment and protect the chloroplast from photooxidative damage as well (Wang et al., 2014; Das \& Roychoudhury, 2014). Moreover, drought is an abiotic stress that produces reactive oxygen species (ROS). According to Das \& Roychoudhury (2014) carotenoids as pigment that produced in chloroplast and other organelles (nongreen plastids) involved in the non-enzymatic detoxification of ROS.

Oil palm transgenic significantly $(p<0.05)$ had higher proline content than that non-transgenic plantlets (Figure 5a). In addition, the proline content also increased during the stress especially, in the transgenic plantlets. A higher increase of proline content was shown by transgenic compared to non-transgenic plantlets (Figure $5 \mathrm{~b}$ ). The proline content of transgenic under 4\% PEG-6000 at 14 DAT increased by $273 \%$, while in nontransgenic plantlets increased by $102 \%$.

The presence of P5CS transgene that controlled by $35 \mathrm{~S}-\mathrm{CaMV}$ promoter caused the increase of proline content in oil palm transgenic plantlets during stress. Toruan-Mathius et al. (2004) stated that proline content is one of the biochemical marker of drought stress in oil palm. In our present study, the proline content in transgenic plantlets sharply increased during the stress. Borgo et al. (2015) stated that proline accumulation is related to the tolerance level of Vigna aconitifolia under drought stress conditions. Proline is suggested to be involved in the chloroplast protection by quenching reactive oxygen species in Arabidopsis thaliana (Moustakas et al., 2011).

Various studies found that proline content also increased after treated with drought stress. The P5CS-transgenic tobacco showed increase of proline content compared non-transgenic ranged 3618 - 4449 and $2044 \mu \mathrm{g} / \mathrm{g}$ fresh weight, respectively (Riduan et al., 2010). The increase of proline content in those transgenic plants improved the tolerance level to drought stress.

P5CS gene expression in transgenic oil palm increased during stresses

The increase of proline content was in line with the increase of P5CS gene expression. The increase of P5CS gene expression in transgenic plantlets under 2 and 4\% PEG-6000 was higher than that of in non-transgenic plantlets (Figure 6). This result supported the hypothesis about the tolerance level of transgenic oil palm related to the increase of proline accumulation. According to Fichman et al. (2015) $\Delta^{1}$-pyrroline-5-carboxylate synthetase which is encoded by P5CS is one of the key enzyme in proline biosynthesis. The increase of proline content also reported that no toxic effect to mitochondria and chloroplast ultrastructure of VaP5CS129A transgenic plants under 12 days of water deficit conditions (Borgo et al., 2015).

Relationship between physiological and P5CS gene expression level in oil palm during PEG-6000 stress treatment

Carotenoids significantly $(p<0.05)$ and positively correlated with chlorophyll content at 7 and 14 DAT. In addition, the P5CS gene expression at 7 and $14 \mathrm{DAT}$ also showed positive correlation with proline content (Figure 7). Bandurska et al. (2017) also reported positive correlation between proline content and activity of P5CS protein in barley (Hordeum vulgare L.) under drought stress. Our present study showed a significantly negative correlation $(p<0.05)$ between leaf drought level score and chlorophyll content (Figure 7). As a consequence of drought level increased, the chlorophyll content of oil palm in leaves tissues decreased. 

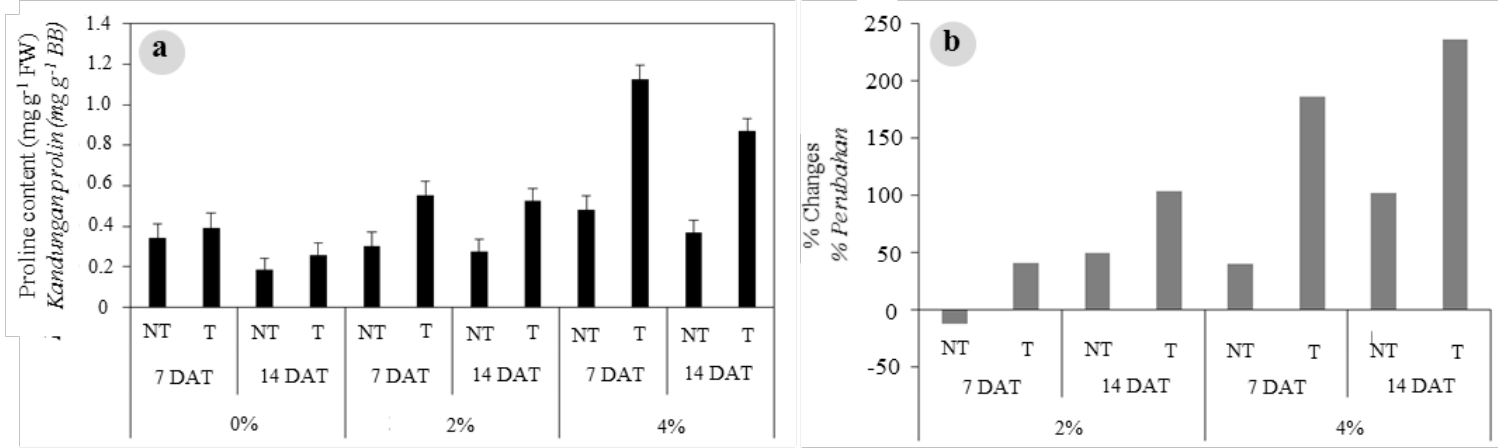

Figure 5. Proline content of oil palm plantlets in 0,2 , and $4 \%$ PEG-6000 during 14 days of in-vitro treatment. NT $=$ non-transgenic; $\mathrm{T}=$ transgenic. DAT $=$ day after treatment; 7 and $14=$ duration of treatment. $\%$ changes means percentage of increase/decrease in each parameter that calculated using formula $=(\mathrm{PEG}$ treatment control)/control x 100\%

Gambar 5. Kandungan prolin planlet kelapa sawit pada 0, 2, dan 4\% PEG-6000 selama 14 hari perlakuan secara invitro. $N T=$ non-transgenik; $T=$ transgenik. $H S P=$ hari setelah perlakuan; 7 dan $14=$ lama perlakuan. $\%$ perubahan berarti persentase peningkatan/penurunan pada setiap peubah yang dihitung menggunakan rumus $=($ perlakuan PEG - kontrol $) /$ kontrol $x 100 \%$

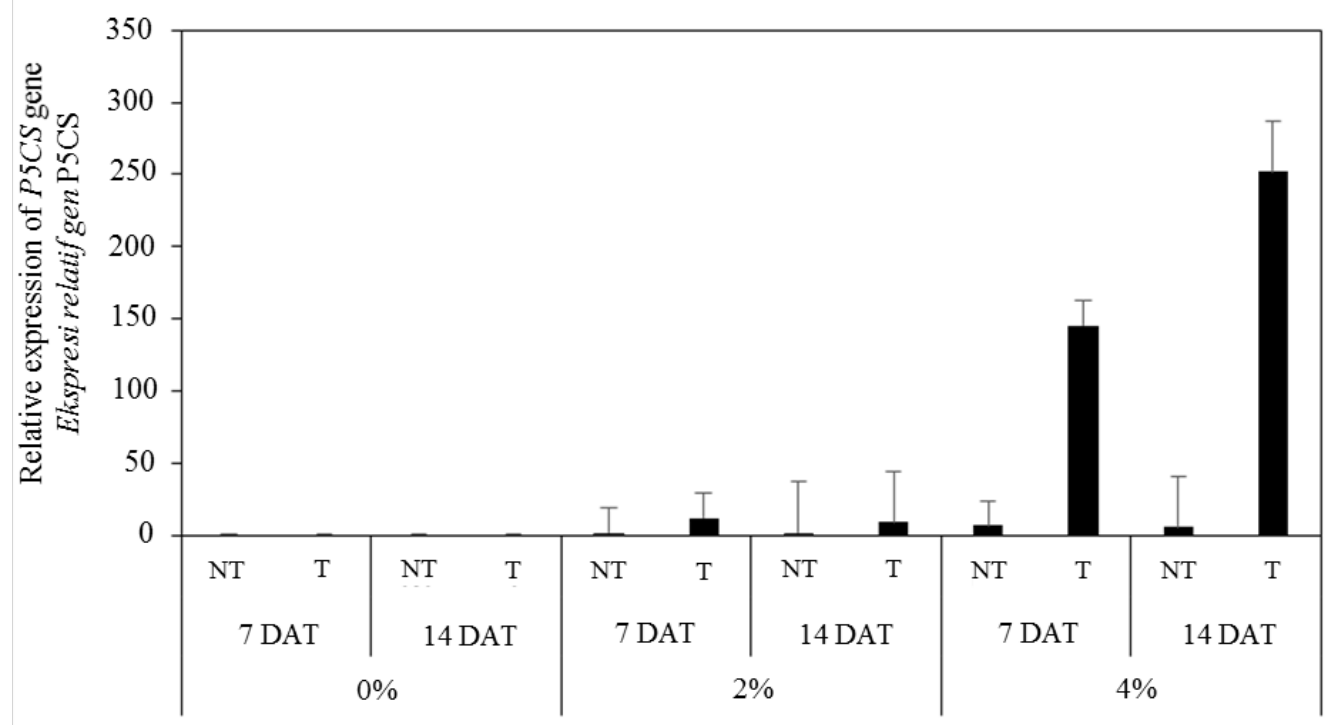

Figure 6. P5CS gene expression level of oil palm plantlets in 0, 2, and 4\% PEG-6000 during 14 days of in-vitro treatment. NT $=$ non-transgenic; $\mathrm{T}=$ transgenic. $\mathrm{DAT}=$ day after treatment; 7 and $14=$ duration of treatment

Gambar 6. Ekspresi relatif gen P5CS planlet kelapa sawit pada 0, 2, dan 4\% PEG-6000 selama 14 hari perlakuan secara in-vitro. $N T=$ non-transgenik; $T=$ transgenik. $H S P=$ hari setelah perlakuan; 7 dan $14=$ lama perlakuan 

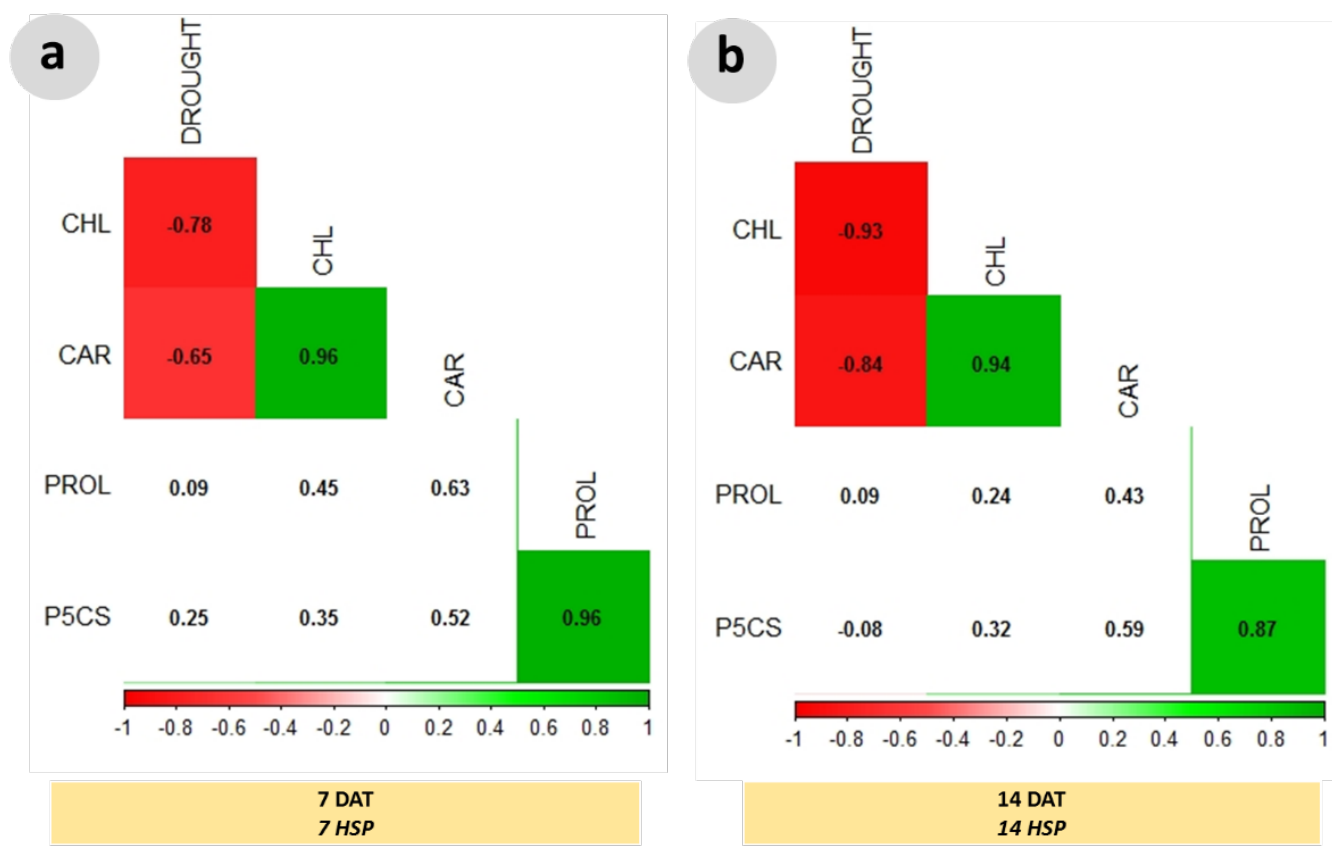

Figure 7. Pearson's correlation coefficient between physiological parameter and P5CS gene expression in oil palm plantlets under PEG-6000 treatment during 7 (a) and 14 (b) days. DROUGHT = drought level score; $\mathrm{CHL}=$ total chlorophyll content; $\mathrm{CAR}=$ Carotenoids content; $\mathrm{PROL}=$ proline content; $\mathrm{P} 5 \mathrm{CS}=$ P5CS gene expression. Correlation analysis was performed at $\alpha=0.05$. Red colour indicates significantly negative correlated; Green colour indicates significantly positive correlated; Without colour indicates non-significantly correlated. DAT $=$ day after treatment; 7 and $14=$ duration of treatment

Gambar 7. Koefisien korelasi Pearson antara peubah fisiologi dan ekspresi gen P5CS planlet kelapa sawit pada perlakuan PEG-6000 selama 7 (a) dan 14 (b) hari. DROUGHT = skor tingkat kekeringan; $C H L=$ kandungan klorofil total; $C A R=$ kandungan karotenoid; $P R O L=$ kandungan prolin; $P 5 C S=$ ekspresi gen $\mathrm{P} 5 \mathrm{CS}$. Analisis korelasi dilakukan pada $\alpha=0,05$. warna merah menandakan signifikan berkorelasi secara negatif; warna hijau menandakan signifikan berkorelasi secara positif; tanpa warna menandakan tidak berkoreasi secara signifikan. HSP = hari setelah perlakuan; 7 dan 14 = lama perlakuan

\section{Conclusion}

Drought stress induced by PEG-6000 resulted physiological changes in oil palm transgenic plantlets showing improved drought tolerance potential. The 4\% PEG-6000 clearly showed different response between P5CS-transgenic and non-transgenic oil palm plantlets on their leaves drought level score. The drought stress during 14 days treatment significantly decreased chlorophyll and carotenoids content in non-transgenic plantlets, while in transgenic planlets. The P5CStransgene increased the tolerance level of oil palm under PEG-6000 stress as shown by the increasing of proline accumulation and $P 5 C S$ gene expression in leaf tissues.

\section{Acknowledgements}

This research is part of the research project entitled "Pengembangan Bibit Klonal Kelapa Sawit Toleran Ganoderma Secara Cisgenik" ("Development of Tolerant Oil Palm Clonal Seedlings to Ganoderma using Cisgenic Approach") funded by BPDPKS (Badan Pengelola Dana Penelitian Kelapa Sawit), Republic of Indonesia.

\section{References}

Abbas SR, SD Ahmad, SM Sabir \& AH Shah (2014). Detection of drought tolerant sugarcane genotypes (Saccharum officinarum) using lipid peroxidation, antioxidant activity, glycinebetaine and proline contents. J Soil Sci Plant Nutr 14(1), 233-243.

Amanah DM, Nurhaimi-Haris \& LP Santi (2019). Physiological responses of bio-silica-treated oil palm seedlings to drought stress. Menara Perkebunan 87(1), 20-30.

Ashraf M (2010). Inducing drought tolerance in plants: recent advances. Biotechnol Adv 28, 169-183.

Azzeme AM, SNA Abdullah, MA Aziz \& PEM Wahab (2016). Oil palm leaves and roots differ in physiological response, antioxidant enzyme activities and expression of stress-responsive genes upon exposure to drought stress. Acta Physiol Plant 38, 52. 
Bandurska H, J Niedziela, Mał. Pietrowska-Borek, K Nuc, T Chadzinikolau \& D Radzikowska (2017). Regulation of proline biosynthesis and resistance to drought stress in two barley (Hordeum vulgare L.) genotypes of different origin. Plant Physiol Biochem 118, 427-437.

Bates LS, RP Waldren \& ID Teare (1973). Rapid determination of free proline for water-stress studies. Plant Soil 39, 205-207.

Borgo L, CJ Marur \& LGE Vieira (2015). Effects of high proline accumulation on chloroplast and mitochondrial ultrastructure and on osmotic adjustment in tobacco plants. Acta Sci Agron 37(2), 191-199.

Badan Pusat Statistik (Indonesian Statistics) (2019). Indonesian Oil Palm Statistics 2018. Jakarta: Statistics Indonesia.

Budiani A, IB Nugroho, H Minarsih \& I Riyadi (2019). Regeneration of P5CS-transformed oil palm plantlets mediated by Agrobacterium tumefaciens. Menara Perkebunan 87(2), 123130.

Cha-um S, N Yamada, T Takabe \& C Kirdmanee (2013). Physiological features and growth characters of oil palm (Elaeis guineensis Jacq.) in response to reduced water-deficit and rewatering. Aust J Crop Sci 7(3), 432-439.

Cha-um S, T Takabe \& C Kirdmanee (2010). Osmotic potential, photosynthetic abilities and growth characters of oil palm (Elaeis guineensis Jacq.) seedlings in responses to polyethylene glycol-induced water deficit. Afr J Biotechnol 9(39), 6509-6516.

Cha-um S, T Takabe \& C Kirdmanee (2012). Physio-biochemical responses of oil palm (Elaeis guineensis Jacq.) seedlings to mannitoland polyethylene glycol-induced iso-osmotic stresses. Plant Prod Sci 15(2), 65-72.

Corley RHV \& PB Tinker (2016). The Oil Palm. Chichester: Blackwell Science.

Darlan NH, I Pradiko, Winarna \& HH Siregar (2016). Dampak el niño 2015 terhadap performa tanaman kelapa sawit di Sumatera bagian tengah dan selatan. $J$ Tanah dan Iklim 40(2), 35-42

Das K \& A Roychoudhury (2014). Reactive oxygen species (ROS) and response of antioxidants as ROS-scavengers during environmental stress in plants. Front Environ Sci. 2, 53.

Din J, SU Khan, I Ali \& AR Gurmani (2011). Physiological and agronomic response of canola varieties to drought stress. J Anim Plant Sci, 21(1), 78-82.

Farooq M, M Hussain, A Wahid \& KHM Siddique (2012). Drought Stress in Plants: An Overview.
In: Aroca R (ed). Plant Responses to Drought Stress: From Morphological to Molecular Features. Berlin: Springer-Verlag.

Fauzi WR \& ETS Putra (2019). Dampak pemberian kalium dan cekaman kekeringan terhadap serapan hara dan produksi biomassa bibit kelapa sawit (Elaeis gueenensis Jacq.). $J$ Pen Kelapa Sawit 27(1), 41-56.

Fichman Y, SY Gerdes, H Kovács, L Szabados, A Zilberstein \& LN Csonka (2015). Evolution of proline biosynthesis: enzymology, bioinformatics, genetics, and transcriptional regulation. Biol Rev Cambridge Philosophical Soc 90(4), 1065-1099.

Galeano E, TS Vasconcelos, PN de Oliveira \& H Carrer (2019). Physiological and molecular responses to drought stress in teak (Tectona grandis L.f.). PLoS ONE 14(9): e0221571.

Ghobadi M, Taherabadi S, Ghobadi ME, Mohammadi GR \& Jalali-Honarmand S (2013). Antioxidant capacity, photosynthetic characteristics and water relations of sunflower (Helianthus annuus L.) cultivars in response to drought stress. Ind Crops Prod 50, 29-38.

Indonesian Rice Research Institute (2002). Standart Evaluation System for Rice (SES). Manila: Indonesian Rice Research Institute.

Iskandar HM, D Widyaningrum \& S Suhandono (2014). Cloning and characterization of P5CS1 and P5CS2 genes from Saccharum officinarum L under drought stress. J Tropical Crop Sci 1(1), 23-30.

Jazayeri SM, YD Rivera, JE Camperos-Reyes \& HM Romero (2015). Physiological effects of water deficit on two oil palm (Elaeis guineensis Jacq.) genotypes. Agron Colomb 33(2), 164173.

Kaur G \& B Asthir (2017). Molecular responses to drought stress in plants. Biol Plant 61(2), 201209.

Kishor PBK, S Sangam, RN Amrutha, PS Laxmi, KR Naidu, KRSS Rao, S Rao, KJ Reddy, P Theriappan \& N Sreenivasulu (2005). Regulation of proline biosynthesis, degradation, uptake, and transport in higher plants: Its implication in plant growth and abiotic stress tolerance. Current Sci (88), 424438 .

Lichtenthaler HK (1987). Chlorophylls and carotenoid: pigments of photosynthetic biomembranes. Methods Enzymol 148, 350382.

Lum MS, MM Hanafi, YM Rafii \& ASN Akmar (2014). Effect of drought stress on growth, proline and antioxidant enzyme activities of upland rice. J Anim Plant Sci, 24(5), 14871493. 
Man D, Bao YX \& Han LB (2011). Drought tolerance associated with proline and hormone metabolism in two tall fescue cultivars. HortSci 46(7), 1027-1032.

Mibei EK, Ambuko J, Giovannoni JJ, Onyango AN \& Owino WO (2017). Carotenoid profiling of the leaves of selected African eggplant accessions subjected to drought stress. Food Sci Nutr 5(1), 113-122.

Minarsih H, D Santoso \& N Fitranti (2001). Identification of P5CS gene on sugarcane by PCR using heterologous primer. Menara Perkebunan 69(1), 1-9.

Minarsih H, D Subiyarti, I Riyadi, SM Putra \& L Ambarsari (2015). Evaluasi varietas, sumber eksplan dan strain Agrobacterium terhadap keberhasilan transformasi tebu dengan gen P5CS. Menara Perkebunan 83(1), 1-9.

Moustakas M, I Sperdouli, T Kouna, CI Antonopoulou \& I Therios (2011). Exogenous proline induces soluble sugar accumulation and alleviates drought stress effects on photosystem II functioning of Arabidopsis thaliana leaves. Plant Growth Regul 65(315), 1-10.

Pavei D, MC Gonçalves-Vidigal, AR Schuelter, I Schuster, ESN Vieira, ECG Vendruscolo \& JP Poletine (2016). Response to water stress in transgenic ( $p 5 c s$ gene) wheat plants (Triticum aestivum L.). Australian J Crop Sci 10(6), 776783.

Riduan A, H Aswidinnoor, Sudarsono, D Santoso \& Endrizal (2010). Toleransi tembakau transgenik yang mengekspresikan gen P5CS terhadap stres kekeringan. J Pengkajian dan Pengembangan Teknologi Pertanian 13(2), 107-118.

Rivera-Mendes YD, JC Cuenca \& HM Romero (2016). Physiological responses of oil palm (Elaeis guineensis Jacq.) seedlings under different water soil conditions. Agron Colomb 34(2), 163-171

Schmittgen TD \& KJ Livak (2008). Analyzing real-time PCR data by the comparative CT method. Nat Protoc 3, 1101-1108.

Talebi R, Ensafi MH, Baghebani N, Karami E \& Mohammadi K (2013). Physiological responses of chickpea (Cicer arietinum) genotypes to drought stress. Environ Exp Bot 11, 9-15.
Todaka D, Y Zhao, T Yoshida, M Kudo, S Kidokoro, J Mizoi, KS Kodaira, Y Takebayashi, M Kojima, H Sakakibara, K Toyooka, M Sato, AR Fernie, K Shinozaki \& K Yamaguchi-Shinozaki (2017). Temporal and spatial changes in gene expression, metabolite accumulation and phytohormone content in rice seedlings grown under drought stress conditions. Plant J 90, 61-78.

Toruan-Mathius N, T Liwang, I Danuwikarsa, G Suryatmana, H Djajasukanta, D Saodah \& IGPW Astika (2004). Respons biokimia beberapa progeni kelapa sawit (Elaeis guineensis Jacq.) terhadap cekaman kekeringan pada kondisi lapang. Menara Perkebunan 72(2), 38-56.

Turhadi T, H Hamim, M Ghulamahdi \& M Miftahudin (2019). Iron toxicity-induced physiological and metabolite profile variations among tolerant and sensitive rice varieties. Plant Signaling \& Behav 14(12), e1682829.

Voronin PY, SN Maevskaya \& MK Nikolaeva (2019). Physiological and molecular responses of maize (Zea mays L.) plants to drought and rehydration. Photosynthetica 57(3), 850-856.

Wang Y, X Jiang, K Li, M Wu, R Zhang, I Zhang \& G Chen (2014). Photosynthetic responses of Oryza sativa L. seedlings to cadmium stress: physiological, biochemical and ultrastructural analyses. Biometals 27, 389-401.

Yehouessi LW, L Nodichao, H AdoukonouSagbadja \& C Ahanhanzo (2019). Genotypic variability in oil palm (Elaeis guineensis Jacq.) towards drought damages in Benin (West Africa). Internat J Biol Chem Sci 13(3), 17371746.

Zarattini M \& G Forlani (2017). Toward Unveiling the Mechanisms for Transcriptional Regulation of Proline Biosynthesis in the Plant Cell Response to Biotic and Abiotic Stress Conditions. Front Plant Sci 8, 927.

Zarei S, AA Ehsanpour \& J Abbaspour (2012). The role of over expression of P5CS gene on proline, catalase, ascorbate peroxidase activity and lipid peroxidation of transgenic tobacco (Nicotiana tabacum L.) plant under in vitro drought stress. J Cell Molecular Res 4(1), 4349. 